\title{
Factors Influencing Loan Repayment in Micro-Finance Institutions in Kenya
}

\author{
Florence Angaine ${ }^{1}$, Daniel Nderi Waari ${ }^{2}$ \\ ${ }^{1}$ School of Management, Kenya Institute of Management, MERU P.O. BOX 2602-60200, MERU \\ ${ }^{2}$ Jomo Kenyatta University of Agriculture and Technology, P.O BOX 3589-00200, Nairobi, Kenya
}

\begin{abstract}
Access to finance by entrepreneurs is paramount for their business to succeed. The existing microfinance institutions (MFI's) have tried to bridge the gap of credit accessibility to entrepreneurs but despite this the entrepreneurs have been defaulting on their loans. This study was carried out to analyze the factors influencing loan repayment in micro-finance institutions. The findings will assist the microfinance institutions in coming up with the most appropriate measures to apply in order to eliminate defaults. Descriptive survey was employed with a target population of 39 Loan Officers and 5280 registered MFI clients. A census of 39 loan officers was targeted and a sample size of 360 respondents from registered group members. Stratified proportionate sampling and simple random sampling were employed. Data was collected by use of questionnaires and interviews and analyzed using both descriptive and inferential statistics. The study established that education level, number of dependents, and hobbies were individual characteristics influencing loan repayment. Business characteristics influencing loan repayment were: length of operation, management and type of business. While the lenders characteristics were: groups handled, period taken to qualify new members and the criteria used to evaluate credit worthiness. The study recommends that the government and other stakeholders in the sector should ensure that prospective financial borrowers have access to formal education and training on business management and financing. The MFI's should reduce the time taken to process a loan application and develop models that are more effective in evaluating credit worthiness of their clients.
\end{abstract}

Keyword: Default, Group official, Loan, Loan officer, Micro Enterprise, Microfinance

\section{Introduction}

The growth of the Micro-finance sector has been tremendous in Kenya with some transforming to banks and deposit taking institutions [1]. These institutions offer medium amounts of loans mostly to business people who cannot afford collaterals to get loans from the big commercial banks. It is in this regard that this study was designed to determine the factors influencing loan repayment by Micro-finance clients within Meru Municipality.

It is feared that the rapid proliferation of MFIs has outpaced the capacity of developing world governments to implement sustainable regulatory measures thus creating a wild environment in which borrowers with limited financial experience are exploited by incompetent or unscrupulous lenders [2].In 2005, for example, government regulators in Kenya closed Akiba MFI for unlawfully taking customers deposits and reneging on payments [3]. [4] Found out that under a group lending scheme, the burden of risk borne by an individual member of a group is higher than it would have been under a limited liability scheme. A default by one borrower affects the credit rating of the group as whole and causes them to default.

Much research has been done on the lending criteria to be used, however not much has been on the reasons as to why people fail to pay their loans even after meeting the minimum criteria. [5, 6]argues out that Micro finance should not use collaterals instead it should make use of the three C's of credit. Character being the first C, refers to how a person has handled past debt obligations. It can be evaluated from credit history, personal background, honesty and reliability of the borrower. The next one is capacity; this means how much debt a borrower can comfortably handle. Income streams are analyzed and any legal obligations looked into, which could interfere with payments. Finally capital, this means current available assets of the borrower, such as real estate, savings or investment that could be used to repay debt if income should be unavailable. The three C's minimum criteria is very hypothetical as borrowers still find themselves in a situation that they are unable to meet their debt obligations. This means that more is required that just meeting this minimum criteria.

Other models such as the village bank model or group liability model argue that the group pressure should be enough to make a potential defaulter pay up his dues. However the assumption here is that the defaulter has the capability and not the will. The model will not work where the borrower lacks the capability and despite the pressure he still cannot pay up the loan. The study will dig into the issues that make 'good borrowers' to become 'bad borrowers' so that the 'badness' in the borrower can be minimized and eliminated if possible 
The purpose of this study was to determine the factors influencing loan repayment default in MicroFinance Institutions within Meru Municipality.However the specific objectives of the study were to:

i). Investigate the client characteristics that influence loan repayment in Micro-Finance Institutions.

ii). Analyze business characteristics that influence loan repayment in Micro-Finance Institutions.

iii). Establish lender's characteristics that contribute to loan repayment among Micro-Finance Institutions.

The study has four main parts. First there is discussion on the existing literature review concerning loan repayment and the operations of microfinance. Secondly the methodology to be employed is covered. Next is the research findings and finally the conclusion. The conclusion covers the managerial implications of the findings and the recommendations of the study.

\section{Loan Repayment}

According to [7], Kenya's microfinance is one of the oldest and most thriving in Africa but affected by loan repayment problems. The establishment of the MFIs was initiated and propelled by the International Labour Organization (ILO)[8] report of 1972. This report coupled with the sessional paper on Juakali brought to fore the economic contribution of the informal sector. This led to organizations like National Council of Churches of Kenya (NCCK) to start a scheme of providing credit to the informal sector. This was followed suit by other organizations like KREP, FAULU, CARE-WEDCO, PRIDE and KWFT [9]. The programs ran by these institutions were highly subsidized as they had a link to the donor funding. Due to increased proliferation of MFIs in 2000, the government enacted the microfinance Act of 2006to regulate their operations [10].

This study is motivated by the contract theory and motivation theory which highly associate the commitment to a task or obligation toa defined motive or end goal. According to [11] an optimal contract is a principal-agent problem that is comprehensive in that it specifies each party's obligations under each state of nature. In group lending commitment maybe exemplified through on-time loan repayment or throughfrequency of attendance to group meetings. The contracts may be either informal or formal, open or closed but the bottom line is the obligation imposed to the parties - lenders and borrowers.

The needs of an entrepreneur may be depicted using the Maslow's hierarchy of needs and as [12] argues, default may arise if an entrepreneur who is yet to meet the lower needs accesses credit. This credit will first be used to meet his lower level needs instead of being invested in the enterprise. According to [13], an individual who has moved upwards to the next level, needs in the lower level will no longer be prioritized but if a lower set of needs is no longer being met, the individual will temporarily re-prioritize those needs by focusing attention on the unfulfilled needs although the individual will not permanently regress to the lower level.Thus this may explain non loan repayment in some instances.

\subsection{Lender's Characteristics that Influence Loan Repayment}

The lenders characteristics include their policies, attributes, objectives and work performances that govern the lending criteria. Beside the three C's model of lending that is character, capacity, capital,[14]does insist that MFI's should evaluate clients on collateral and prevailing financial condition of the borrower. Past financial statements i.e. the balance sheets and income statements are reviewed in terms of key profitability and credit ratios, inventory turnover, ageing of accounts receivable, the entrepreneur's capital invested and commitment to the business. Future projections on market size, sales and profitability are also evaluated to determine the ability to repay the loan [15].

[14]discusses the various models that MFIs have used in lending to clients these models rank from group lending, village banks, ROSCAs and Cooperatives. The rules of borrowing are usually determined by the members forming these associations. [14] and [16] further argue that the MFI may determine the credit worthiness of borrowers through discriminant analysis technique which is more objective in determining good and bad customers. On the other hand to save time the MFIs can turn to loan officers in evaluating prospective clients [17].

[12]does fault the conduct and mode of operation of most of the MFIs. According to him there is no sufficient monitoring and reporting to ensure funds are used for the purpose preferred by terms of MFIs. Some clients borrow from one lender to pay other lenders and repayment of credit may not be a good indicator for total success of MFIs hence to achieve preferred goals there is need for shift of both strategy and approach.

\subsection{Borrowers Characteristics that Influence Loan Repayment}

According to [5]the main characteristics that define a borrower's ability to repay the loan include character, capacity and capital. Many financial institutions besides using other models of evaluating borrowers do make use of the 3 C's model. The Character of a customer is important to analyse his willingness to pay. The financial or credit manager should judge whether the customers will make lowest effort to honour their credit obligations. The moral factor is of considerable importance in credit evaluation in practice [18]. 
Empirical work done by [19]revealed that income, farm size, age of farmers, farming experience and level of education of farmers contributed positively to the credit worthiness of farmers. Much consideration has been given on financial aspects of the entrepreneurs ignoring the entrepreneur aspect that is the human capital. According to [20] much of the microfinance industry focuses on the infusion of financial capital into micro enterprises, not human capital, as if the entrepreneurs either already have the necessary human capital. Some development practitioners however, actively pursue strategies to teach adults entrepreneurial skills [21] "I firmly believe that all human beings have an innate skill. The fact that they are alive is clear proof of their ability.However a growing number of microfinance institutions are attempting to build the human capital of micro entrepreneurs in order to improve the livelihood of their clients and help further in their mission of poverty alleviation [22].

Human capital has been found to be of great influence to the borrower's ability to repay the loan. This was supported by [22], through a randomized control trial which established that the treatment group that were provided with entrepreneurship training in their monthly meeting had better repayment rates. This is further supported by [23] and [24], who further insists on formation of credit referencing bureaus for assisting the industry in sharing borrowers' information thus reducing the default rate.

According to [25], the main causes of default are illness and death not lack of skills. He recommended that Micro - enterprise can help people onto the path out of poverty and educate them about how to protect themselves from Aids, TB and malaria can help keep them and their families and communities on that path.

[26]found out that repayment performance is significantly affected by borrowers' characteristics, lender's characteristics and loan characteristics. The marginal effects of each set of characteristics are determined and analyzed. Repayment problems can be in the form of loan delinquency and default. Whatever the form however, the borrowers alone cannot be held responsible wherever problems arise as it is important to examine the extent to which both borrowers and leaders comply with the loan contract as well as the nature of the duties, responsibilities and obligations of both parties as reflected in the design of the Credit programme rather than heaping blames only on the borrowers. In his research he further found out that loan repayment default is caused by sickness of the borrower [14].

\subsection{Business characteristics that influence loan repayment}

Business characteristic may include factors like location, registration that is formal or informal, size, nature and type of business it is involved in. In addition [27] does try to define the size of business to the amount of income that the business generates. [27] establishes a link between the incomes of a business to the nature of collaterals that the business offers to the lenders. According to [28] the business characteristic may extend to the nature of collateral it offers for the credit.

[28]also asserts that the value of the collateral to the lender varies according to several factors. Perhaps the most important is the marketability. If collateral can be sold quickly in an active market without depressing the price, the lender is likely to be willing to lend an amount that represents a fairly high percentage of the collateral's stated value. On the other hand, if the collateral is a special purpose machine designed specifically for a company and it has no viable secondary market, the lender may choose to lend nothing at all.

The life of the collateral also matters. If the collateral has a cash flow life that closely parallels the life of the loan, it will be more valuable to the lender than collateral that is much longer term in nature. As the collateral is liquidated into cash, the proceeds may be used to pay down the loan. Still another factor is the riskiness associated with the collateral. The greater the fluctuation in its market value or the more uncertain the lender is concerning market value, the less desirable the collateral from the stand point of the lender. Thus, marketability, life, and riskiness determine the attractiveness of various types of collateral to a lender and, hence, the amount of financing available to borrower.

\subsection{Conceptualization}

The concept model of this study is to analyze the factors influencing loan repayments in MFIs in Kenya. From literature review, various empirical studies reviewed by the author cite probable factors that influence loan repayments. This study focuses on client characteristics, business characteristics and lender characteristics to carry on empirical study to investigate on the probability of these variables affecting loan repayment by the MFI clients in Kenya. From the conceptualization of the study variables, the conceptual framework is presented as Fig 2.0 


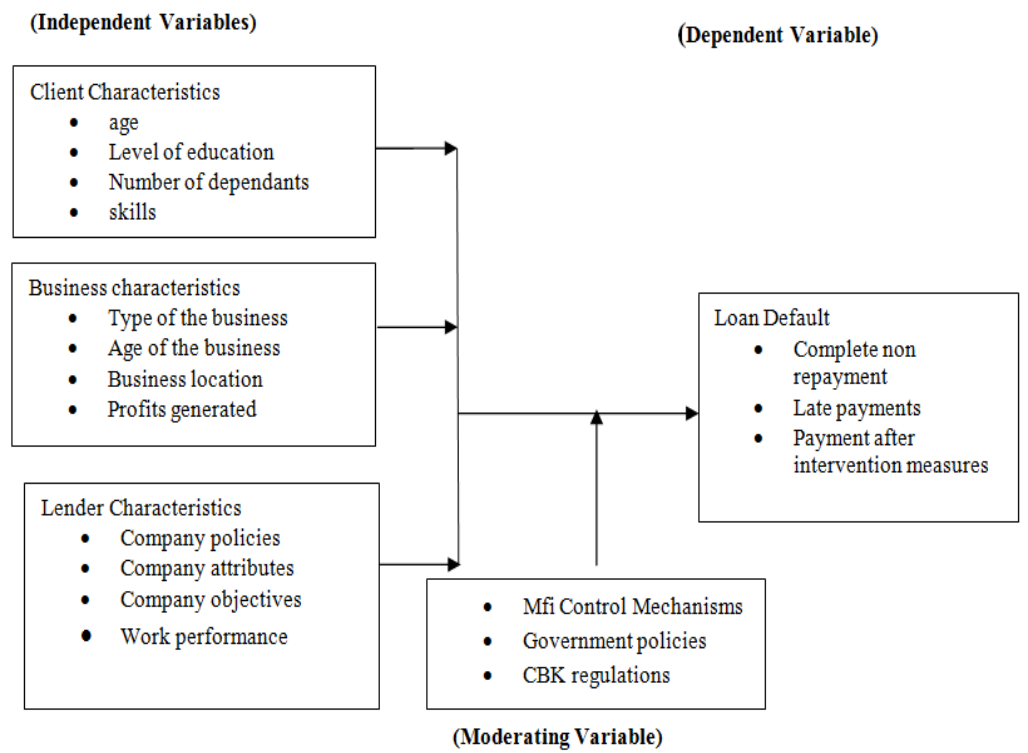

Fig 2.0. Conceptual Framework (Source: Researcher, 2013)

\subsection{Variable Description and Measurement}

This study analysis focuses on a number of MFIs specific factors. The specific factors are assumed to be in the direct control of the MFIs due to the control mechanisms applied like ability to vet each and every loan applicant. The client characteristics are measured by age, education levels, number of dependants a client supports financially and client hobbies. Business characteristics relate to the nature and type of the business plus its performance in relation to the others in the environment. They include the size and age of the business, location, income and profits generated from the business. For instance at higher levels of income, businesses make some savings and purchase assets which can be used as loan securities. Such securities can be sold to repay loans.

Lenders characteristics are factors attributed to the lender which means loans officers, company attributes, MFIs policies and objectives as well as performance of work. The MFIs should be in a position to provide guidance to the stakeholders relating to loan processes and procedures for better repayment and overall portfolio performance. Effective lending procedures have far reaching consequences on the loan repayment. The controlvariables consist of the various operations that ensure security of the loans such as proper market analysis, business screening and follow-up. Without effective mechanisms in place loan defaults are inevitable and loan recovery might be a great challenge for microfinance institutions.

\section{Research Methodology}

The research study adopted a descriptive survey design aimed at establishing the effects of specific factors on loan repayments in MFIs. According to [29] descriptive survey is a method of collecting information by interviewing or administering a questionnaire to a sample of individuals. This design was required in the study because it would minimize bias and maximize the reliability of the data collected.

The total population under study was 39 loan officers and 5280 clients of MFIs under study. Using the stratified proportionate sampling methodology the researcher arrived at a sample of 360 clients. This sample consisted of 185 loan defaulters, 185 consistent loan payers and the 39 loan officers. Thus the total sample that participated in this study was 399 respondents. A structured questionnaire was administered to the respective respondents. The borrowers had a different questionnaire from that administered to the loan officers in recognition of their homogeneity.

After data was collected, it was presented and analyzed using both qualitative and quantitative methods and then presented in percentages. Descriptive analysis which involved summarizing responses from open ended responses was also done using SPSS tool. The researcher also used regression analysis to establish the causal-effect relationship between the variables under study.

\subsection{Client Characteristics}

\section{Findings}

The client's characteristics consisted of gender, age, level of education and number of dependents. Of the male respondents $(55.2 \%)$ defaulted in payments while $(47.5 \%)$ of the females defaulted. This shows that there was no significant difference in loan repayment default between males and females. When age was 
analyzed it was found that $8.1 \%$ of the respondent who were aged above 50 years defaulted in loan repayment, $21.1 \%$ aged between 41 and 50 years defaulted, $30.3 \%$ aged between 31 and 40 defaulted in loan repayment, and $40.5 \%$ aged between 18 and 30 defaulted. This indicates that young people were more likely to default than the old.

When number of dependents effects were analyzed it was found that among respondents supporting 1-2 persons $50.0 \%$ of defaulted, among those supporting 3-5 persons $52.3 \%$ defaulted and among those supporting 6-10 persons $61.5 \%$ defaulted. This indicates that respondents supporting many dependents were likely to default than those supporting fewer dependents. In relation to loan repayment default, $9.76 \%$ of those with primary level eduaction defaulted, $62.93 \%$ of those with secondary level of education defaulted, $47.71 \%$ of those with college level eduation defaulted and $0.0 \%$ of those with university level education defaulted. This demostrate that loan repayment default cases were low among people with post secondary education as compared to those who had upto secondary level of education.

These finding were similar to those obtained by [30]who examined socio-economic factors influencing loan repayment among small scale farmers in Ogbomoso agricultural zone of Oyo State of Nigeria. His results of multiple regression analysis showed that amount of loan obtained by farmers; years of farming experience with credit use and level of education were the major factors that positively and significantly influenced loan repayment.

\subsection{Business Characteristics}

Loan default in microfinance sectors could arise from business related characteristics (Awoke, 2004). In the type of business high cases of default were common $67.9 \%$, in the manufacturing sector. This was followed by the service industry $(64.0 \%)$ then by the agriculture $(58.3 \%)$. Analysis further showed that the trade sector recorded the least (34.9\%) cases of loan repayment defaults. The results are in line with [31] who found out that borrowers' involved in non-production oriented business activities such as services or the support sectors who had training in their particular business and who borrowed higher loans had lower probabilities of defaulting. Among businesses that had been in operation for less than two years $52.4 \%$ had defaulted in loan repayment, $44.2 \%$ of those that had been in operation for a period of between two and five years had defaulted. It was noted that the highest (78.6\%) default cases were regular in businesses that had been in operation for a period of between five and ten years. The study could not account for such an observation. Loan repayment defaults were rare $(0.0 \%)$ in business that had survived for more than 10 years.

\subsection{Lender's Characteristics}

Study findings reveal that $70 \%$ of the officers handled above 5 groups while $30 \%$ of the officers handled 2 to 5 groups. Handling more than five groups had an increased number of cases of loan repayment default $(85.7 \%)$ as compared to those officers handling less than five groups $(66.7 \%)$. Cases of default were highest $(100 \%)$ in those new members who took shorter period to qualify for a loan as compared to $66.7 \%$ in those who took a longer period. $40 \%$ of the officers had the opinion that default in loan payment was largely caused by multi borrowing on the side of the members. This was followed at $20 \%$ by officers who were of the opinion that members defaulted in paying off the loans due to a large number of financial dependants. $10 \%$ of officers were of the opinion that the member failed to honour their loan payments due to business failure and disappearance of customers. $40 \%$ of micro finance institutions handled instalments in default by tapping into group savings. $30 \%$ of the officers made other members to pay for the default while $10 \%$ of micro finance institution followed up the customers and seized their property to recover the loans.

\subsection{Regression Analysis}

Logistic regression was used to investigate the factors influencing loan repayment problem among borrowers in microfinance institutions in Meru Municipality. The maximum likelihood estimation technique was used.

Table 1.0 Likelihood Ratio Tests

\begin{tabular}{|l|l|l|l|l|}
\hline \multirow{2}{*}{ Effect } & Model Fitting Criteria & \multicolumn{2}{l|}{ Likelihood Ratio Tests } \\
\cline { 2 - 5 } & -2 Log Likelihood of Reduced Model & Chi-Square & df & Sig. \\
\hline Intercept & $253.859(\mathrm{a})$ & .000 & 0 &. \\
\hline Gender & 253.995 & .136 & 1 & .712 \\
\hline Age & 309.828 & 55.969 & 3 & .000 \\
\hline Marital status & 323.466 & 69.607 & 3 & .000 \\
\hline Dependents & 273.378 & 19.519 & 2 & .000 \\
\hline Education & 270.172 & 16.313 & 3 & .001 \\
\hline Business type & 268.885 & 15.026 & 3 & .002 \\
\hline Time in Business & 300.976 & 47.117 & 3 & .000 \\
\hline No. of Employees & 286.277 & 32.418 & 3 & .000 \\
\hline
\end{tabular}




\begin{tabular}{|l|l|l|l|l|}
\hline Location & 256.207 & 2.348 & 1 & .125 \\
\hline Manager & 255.824 & 1.965 & 1 & .161 \\
\hline Source of Capital & 278.408 & 24.549 & 3 & .000 \\
\hline
\end{tabular}

The significant positive sign on the gender variable indicated that the probability of a loan repayment problem was higher for males than for females. The business type variable was positive and significant at the $5 \%$ level of significance. This implied that borrowers involved in agriculture, such as farming, animal husbandry and fisheries, were more likely to have a problem repaying the microcredit loan than borrowers involved in a small business activity. The reliance of agriculture on the weather caused fluctuations in production that were beyond the control of the farmers. Hence, since borrowers involved in agricultural activities have a greater problem repaying their loan, Microfinance institutions need to consider giving flexibility in loan repayments to borrowers who receive income irregularly caused by drought or flood.

In relation to individual characteristics, the table above indicates that gender of the respondent was not an important predictor of loan repayment default while age, marital status, number of dependants and education levels of the respondents were useful parameters in the prediction of loan repayment default.

In relation to business characteristics, how long a business has been in existence, management, location of the business and the source of the initial capital seem not to be useful parameters in the prediction of default. On the other hand, the number of employees and the type of the business run appear to be useful parameters in the prediction of loan default.

In relation to lender characteristics, how long an officer has worked for the microfinance institution, the number of groups an officer handles, how long an individual takes before is given a loan, how the worth of a customer is evaluated and consideration for collateral seem not to be useful parameters in the prediction of loan default by group members since these parameters have significance levels below 0.05 .

\section{Conclusions}

Microfinance institutions in Kenya are a potential alternative to bank credit for micro-businesses that cannot receive bank finance. Microfinance institutions are essential to the Government's encouragement of an enterprise culture. Generally in spite of the importance of loan in micro-businesses, its acquisition and repayment are fraught with a number of problems especially repayment default. The study evaluated the factors influencing default in loan repayment in microfinance institutions in Meru Municipality.

Arising from the findings of this study, it concludes that (51.4\%) of group members defaulted in loan repayment. In addition $80 \%$ of the microfinance officers at one time had experienced loan default by members, further evidence of the magnitude of the problem. The respondents cite various reasons that contribute to their default in loan repayment; business idea does not work out, cash flow problems, failure in the business, and lack of liquidity, inadequate sales and undercapitalization.

The study therefore concludes that there are various factors influencing non-repayment of loans which are: the inherent characteristics of borrowers and their businesses that make it unlikely that the loan would be repaid; the characteristics of the lending institution and suitability of the loan product to the borrower which make it unlikely that the loan would be repaid; systematic risk, in the form of external factors, such as the economic, political and business environment in which the borrower operates.

\section{References}

[1] Warue Beatrice ,Factors Affecting Loan Delinquency In Microfinance Institutions In Kenya, International Journal of Management Sciences and Business Research, 2012, Vol. 1, Issue 12. (ISSN: 2226-8235)

[2] Howard, L. and Thierry B. trust in lending: social capital and joint liability seed loans in Southern Zambia.(Lusaka World Development,2006).

[3] WangaiP.N ,Factors that influence demand for credit among small investors. A case of imenti north district, 2008.

[4] AMFI, Micro finance gateway, Kenya micro finance bill, Nairobi Kenya, (2008),

[5] Yunus, M. (1999). Banker To The Poor: Micro Lending And The Battle Against World Poverty. New yolk USA : Public Affairs

[6] Yunus, M. (2003). Halving Poverty By 2015: We Can Actually Make It Happen. New yolk USA: Public Affairs.

[7] Anapum, B. Blavy, R. and Yulek, M. (2004), Micro Finance In Africa: Experience And Lessons From Selected African Countries. International Monetary Fund Working Paper.Wp/04/174.

[8] International Labour Organization, (1972).Kenya: employment, Income and Inequality. Geneva: ILO.

[9] AMFI (2005), Micro finance matters (micro finance newsletter issue of 11th April), Nairobi Kenya

[11] Hart, O., and Holmström, B. (1987)“"The Theory of Contracts” Advances in Economic Theory ed. T. Besley, Cambridge University Press, Cambridge.

[12] Bayang, S.(2009). Why Microfinance Fails To Meet Enterprise Goals. Downloaded from http://www.allgambian.net/enterprise detail.com on $5 / 2 / 2013$

[13] Sagimo, P.O (2002). Towards efficiency, effectiveness \& productivity, Nairobi east publishers limited.

[14] Mwenje, A.W. (2006) kenya women entrepreneurs and access to micro finance services. A case of KWFT (kiambu)

[15] HisrichR.D.,PetersM.p. and Shepherd D.A.(2005). Entrepreneurship, special Indian edition, Mc Graw-Hill, New Delhi

[16] Pande, R. and Burgess, R.,(2005), "Can Rural Banks Reduce Poverty?.”, American Economic Review. The Indian Social Banking Experiment 
[17] Dichter, T,(2003). A Second Look At Micro Finance: The Sequence Of Growth And Credit In Economic History. CenterFor Global Liberty And Prosperity, Development Policy Briefing Paper. Downloaded From http://www.microfinancegateway.org/content/article/detail/31747 on 22-02-2013.

[18] Pandey I. M (2004) financial management $9^{\text {th }}$ edition ,New Delhi.

[19] Arene, C. J. An analysis of loan repayment potentials of smallholder soyabean group farmers in Nigeria. Quarterly Journal of International Agriculture, 1993, 32(1): 160-169.

[20] Barnajee, A. and Newman, A (1993).occupational choice and the process of development journal of political economy. Chicago: university of Chicago press.

[21] Kiiru (1997), Case Study of Kenyan Micro Finance Programme, Africa region number 80 February 1997

[22] Townsend, R. and Paulson, A.L. (2004) Entrepreneurship And Financial Constraints In Thailand. Journal Of Corporate Finace. Downloaded from http://www.elsevier.com

[23] Morduch J and Argion B.A. (2005) the Economics of Micro Finance. themti press Cambridge,MassachusettsLondon,England

[24] Gurinder P. S. K., (2006), "Credit Bureau for the Sub Prime sector in India”, Social Initiatives Group, ICICI Bank Limited, 2006

[25] Leila Nimatallah (2006), Micro-Enterprise and HIV Aids. Lagos Nigeria

[26] Olotomola S. Ade, (2002) Determinant of Smallholder Loan Repayment, Performance, Evidence, Nigerian Micro finance system, Nigeria

[27] Mpunga P. (2004). Demand for credit in rural Uganda: who cares for the peasants? Paper Presented at the Conference on Growth, Poverty Reduction and Human Development in Africa Center for the Study of African Economies. Uganda

[28] Horne James C. Van,(2007) financial management and policy, new Delhi

[29] Orodho J.A (2003). Essentials of Educational and Social Sciencies Research Methods.Nairobi:masola publishers.

[30] Oladeebo J. O. and O.E. Oladeebo. 2008. Determinants of loan repayment among smallholder farmers in Ogbomoso Agricultural Zone of Oyo State, Nigeria. J. Soc. Sci. 17 (1): 59-62

[31] Roslan, A.H. and MohdZainiAbd Karim, "Determinants of Microcredit Repayment in Malaysia: The Case of Agrobank," Universiti Utara Malaysia (IDOSI, 2009).http://www.idosi.org/hssj/hssj4(1)09/6.pdf 